\title{
Isolation and Some Chemical Properties of a New Peptide, Analipine, from a Brown Alga, Analipus japonicus*
}

\author{
Mitsuzo TAKaGi**, Atsushi IIDA**, Hanako Murayama***, \\ and Suga SomA*** \\ (Received May 21, 1973)
}

\begin{abstract}
A new peptide was found in the $75 \%$ ethanol extracts of a brown alga, Analipus japonicus. The peptide was isolated as cross-shaped crystals by gel filtration through Sephadex G-10, ion exchange chromatography on Dowex 50 resin, and mercuric acetate precipitation. The peptide appears to be a pentapeptide consisting of glutamic acid and aspartic acid or their amides, since it gave 1 mole of glutamic acid and 4 moles of aspartic acid on acid hydrolysis. The peptide was named "analipine" after the generic name of the alga.
\end{abstract}

Although many studies on peptides of marine algae have hitherto been performed by a number of researchers ${ }^{1-9)}$, only a few peptides have been isolated purely, namely, eisenine from Eisenia bicyclis ${ }^{10,11)}$, fastigiatine from Pelvetia fastigiata ${ }^{5)}$, and L-arginyl-L-glutamine from a freshwater species of Cladophor ${ }^{12}$.

KONAGAYA ${ }^{13,14)}$ has recently isolated eisenine from Ecklonia cava, a brown alga closely related to Eisenia bicyclis. However, he suggested that the pyrrolidone ring of eisenine must have been secondarily formed during the course of its isolation, as DNP-derivative of Gln-Gln-Ala could be obtained from an aqueous extract of Ecklonia cava.

The present paper deals with the isolation and some chemical properties of a new peptide, "analipine", from a brown alga, Analipus japonicus.

\section{Experimental and Results}

Material The sample of $A$. japonicus was collected on the rocky reef at Shinori in Hakodate on March 10, 1972, and stored at $-20^{\circ} \mathrm{C}$.

Isolation of analipine**** Four $\mathrm{kg}$ of the frozen material was soaked and stirred occasionally in 5 liters of $75 \%$ ethanol for 3 days at room temperature. After filtration, the residue was extracted once more in the same manner. The combined extracts were evap-

* The content of this article was first delivered at the meeting of the Japanese Society of Scientific Fisheries, held in Tokyo in April 1971 and again at the meeting of the same Society, held in Kochi in October 1972 on the occasion of crystallization of "analipine". At the former meeting it was named tentatively "abietinine" after the previous specific name of the alga. However, we adopted analipine in the present paper, as the scientific name was revised to Analipus japonicus by WYNNE ${ }^{15}$ ) in 1971 .

** Laboratory of Food Hygiene, Faculty of Fisheries, Hokkaido University, Hakodate (高木光造. 飯田 優：北海道大学水産学部食品化学第二教室)

*** Course of Nutritional Science, Hakodate Junior College, Hakodate（村山花子・相馬すが：函館 短期大学食物栄養科)

**** In the course of isolation, concentration of solution was carried out under reduced pressure at $55^{\circ} \mathrm{C}$. 
orated to about 2 liters, decolourized with $100 \mathrm{~g}$ of charcoal treated with $5 \%$ acetic acid, and filtered through paper pulp. The resultant light yellow solution was added onto a column of Dowex $50 \mathrm{X}-4\left(\mathrm{H}^{+}, 800 \mathrm{ml}, 100-200 \mathrm{mesh}\right)$, and the column was rinsed with $250 \mathrm{~m} l$ of distilled water to remove mineral salts and other impurities. The adsorbed substances were eluted with $0.2 \mathrm{~N} \mathrm{NH}_{4} \mathrm{OH}$ solution and the eluate was concentrated to $200 \mathrm{~m} l$.

An aliquot $(10 \mathrm{~m} l)$ of the concentrated solution was applied to a column of Sephadex G-10 $(5 \times 100 \mathrm{~cm}, 1000 \mathrm{ml})$ and water was allowed to flow through the column at a rate of $30 \mathrm{~m} l$ per hr, the eluate being collected in $3 \mathrm{~m} l$ cuts. To $0.1 \mathrm{~m} l$ of each fraction $2 \mathrm{~m} l$ of $2 \%$ ninhydrin dissolved in the mixture of equal amount of methylcellosolve and sodium citrate buffer ${ }^{10)}$ of $\mathrm{pH} 5.0$ and $0.1 \mathrm{~m} l$ of stannous chloride solution ${ }^{16)}$ were added. After the
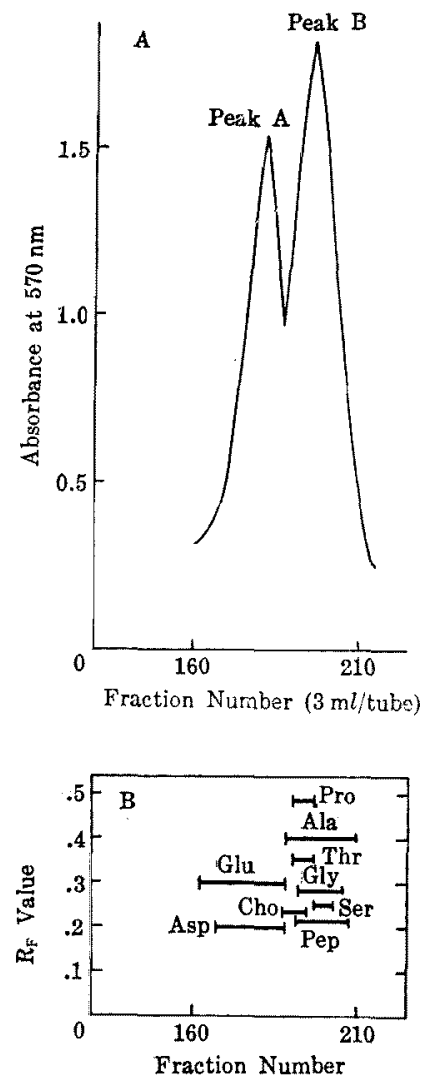

Fig. 1. Gel filtration on Sephadex G-10 of the extract of Analipus japonicus. The column $(5 \times 100 \mathrm{~cm})$ was equilibrated with water and elution was carried out at $30 \mathrm{ml}$ per hr. A, absorbance at $570 \mathrm{~nm}$ after ninhydrin reaction. B, paper chromatography.
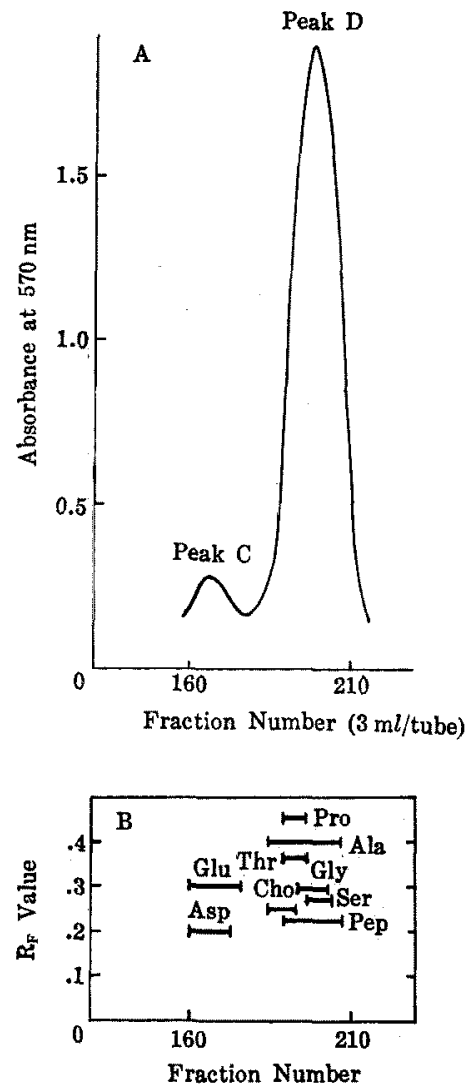

Fig. 2. Gel filtration on Sephadex $G-10$ of peak $B$ in Fig. 1. The condition was the same as that described in Fig. 1. A, absorbance at $570 \mathrm{~nm}$ after ninhydrin reaction. B, paper chromatography. 
mixture was heated for $20 \mathrm{~min}$ in a boiling water bath and diluted with $10 \mathrm{~m} l$ of $n$-butanolwater $(1: 1)$, ninhydrin colour value was measured at $570 \mathrm{~nm}$. Each fraction was also examined by paper chromatography with $n$-butanol-acetic acid-water $(4: 2: 1, \mathrm{~V} / \mathrm{V})$ and Toyo No. 51 paper. Most of aspartic and glutamic acids were eliminated by this treatment (Fig. 1). The gel filtration was carried out 20 times in total, and about 1.5 liters of the pooled solution of peak $B$ was obtained. The above solution was then concentrated to $100 \mathrm{~m} l$ and subjected to the gel filtration on Sephadex G-10 again in the same condition. As shown in Fig. 2, peak D which contains analipine is completely free from aspartic and glutamic acids. The gel filtration was carried out 10 times in total, and about $900 \mathrm{~m} l$ of the solution of peak D was collected.

After the solution of peak D was concentrated to $60 \mathrm{~m} l$, an aliquot $(5 \mathrm{~m} l)$ was applied
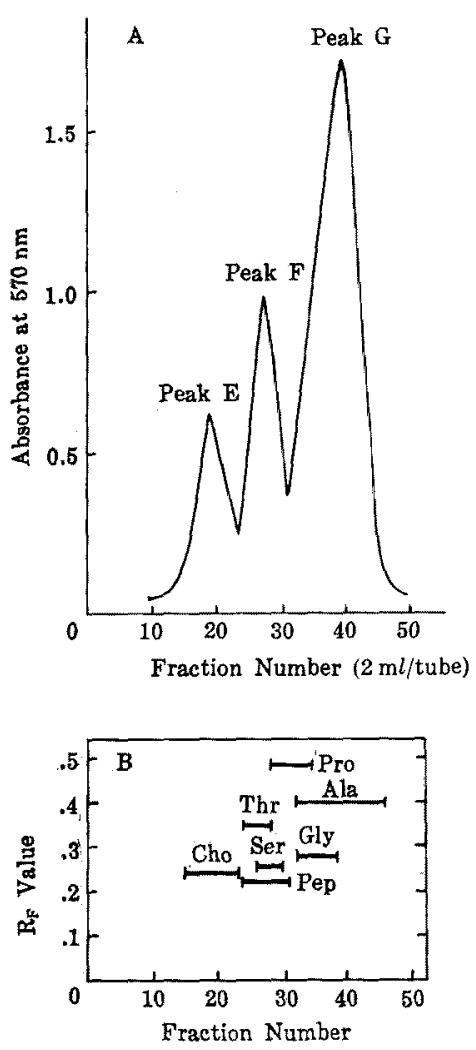

Fig. 3. Ion exchange chromatography of peak $D$ in Fig. 2. Resin, Dowex $50 \mathrm{X}-4\left(\mathrm{Na}^{+}\right)$; column, $0.9 \times 50 \mathrm{~cm}$; buffer, $0.2 \mathrm{~N} \mathrm{Na-citrate}$ $(\mathrm{pH} 3.25)$; temperature, $37^{\circ} \mathrm{C}$. A, absorbance at $570 \mathrm{~nm}$ after ninhydrin reaction. B, paper chromatography.
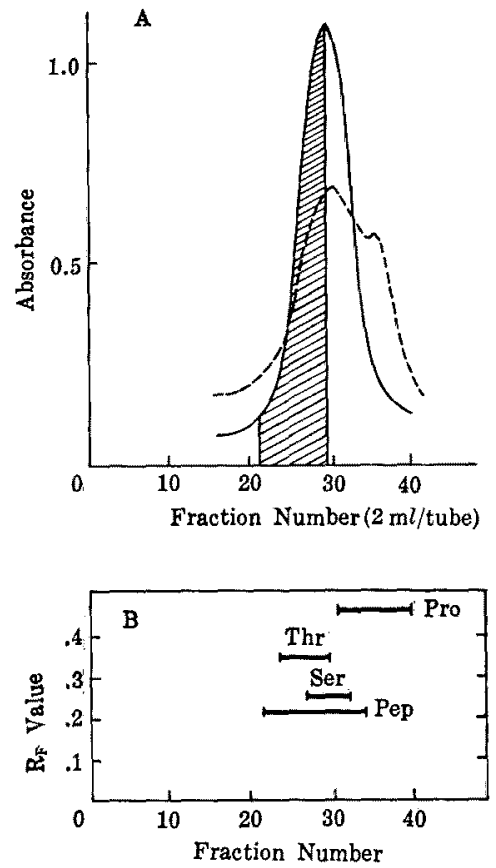

Fig. 4. Ion exchange chromatography of peak $F$ in Fig. 3. The condition was the same as that given in Fig. 3 except that $0.2 \mathrm{~N} \mathrm{Na}$ citrate buffer of $\mathrm{pH} 2.8$ was used. A, absorbance at $570 \mathrm{~nm}(-)$ and $420 \mathrm{~nm}(-\ldots)$ after ninhydrin reaction. B, paper chromatography. 
to a column of Dowex $50 \mathrm{X}-4\left(\mathrm{Na}^{+}, 0.9 \times 50 \mathrm{~cm}, 100-200 \mathrm{mesh}\right)$ equilibrated previously with $0.2 \mathrm{~N}$ sodium citrate buffer of $\mathrm{pH} 3.25$. Elution was carried out with the same buffer at $37^{\circ} \mathrm{C}$ at a flow rate of $24 \mathrm{~m} l$ per hr and $2 \mathrm{ml}$ fractions were collected. A typical elution pattern is shown in Fig. 3. Analipine is eluted in peak F together with threonine, serine, and a part of proline. By repeating this ion exchange chromatography 12 times in total, about $170 \mathrm{~m} l$ of the peptide fraction was collected. The fraction was then concentrated to $30 \mathrm{~m} l$ and subjected to the ion exchange chromatography in the same condition as above to remove proline. The result of a typical experiment is shown in Fig. 4. Although the peptide and proline are overlapping partially, Frs. No. 22 to 29 , the shaded portion in the figure, are destitute of proline. So these fractions were pooled. The ion exchange chromatography was carried out 5 times more. From Frs. No. 30 to 34, the peptide devoid of proline was recovered by the same column chromatographic method. In this way $100 \mathrm{~m} l$ of the peptide solution completely free from proline could be obtained.

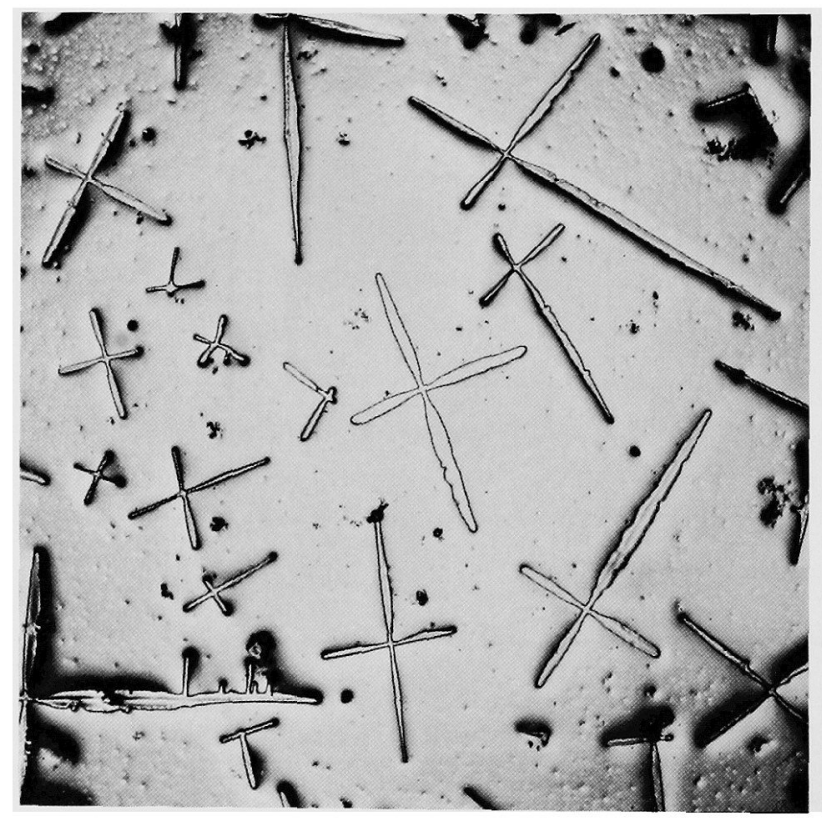

Fig. 5. Crystals of analipine $(\times 100)$.

The peptide solution was passed through a column of Dowex $50 \mathrm{X}-4\left(\mathrm{H}^{+}, 0.9 \times 50 \mathrm{~cm}\right)$, and the column was washed with $50 \mathrm{~m} l$ of distilled water to remove sodium citrate. The peptide was then eluted with $0.2 \mathrm{~N} \mathrm{NH}_{4} \mathrm{OH}$ solution. The eluate was adjusted to $\mathrm{pH} 9$ with $\mathrm{N} \mathrm{NH}{ }_{4} \mathrm{OH}$, and added with $10 \mathrm{ml}$ of $5 \%$ mercuric acetate. The precipitate formed was filtered, suspended in $20 \mathrm{~m} l$ of water, and decomposed with $\mathrm{H}_{2} \mathrm{~S}$. The precipitate of mercuric sulfide was filtered off. 
Table 1. Paper chromatography of analipine.

\begin{tabular}{lcl}
\hline \multicolumn{1}{c}{ Solvents } & $\mathrm{R}_{\mathrm{F} \text { values }}$ & Colour \\
\hline$n$-Butanol-acetic acid-water $(4: 2: 1)$ & 0.22 & blue purple \\
$n$-Butanol-acetic acid-water $(4: 1: 5)$ & 0.15 & purple brown \\
upper phase & & \\
$n$-Butanol-ethanol-water $(4: 1: 2)$ & 0.13 & blue purple \\
Pyridine-water $(4: 1)$ & 0.14 & purple brown \\
Pyridine- $n$-butanol-water $(2: 1: 1)$ & 0.13 & purple brown \\
Collidine-lutidine $(1: 3)$ & 0.02 & purple \\
Lutidine-aniline-water $(9: 1: 2)$ & 0.10 & purple \\
Phenol, water saturated & 0.08 & purple \\
Benzyl alcohol, water saturated & 0.01 & purple \\
\hline
\end{tabular}

Paper, Toyo No. 51.

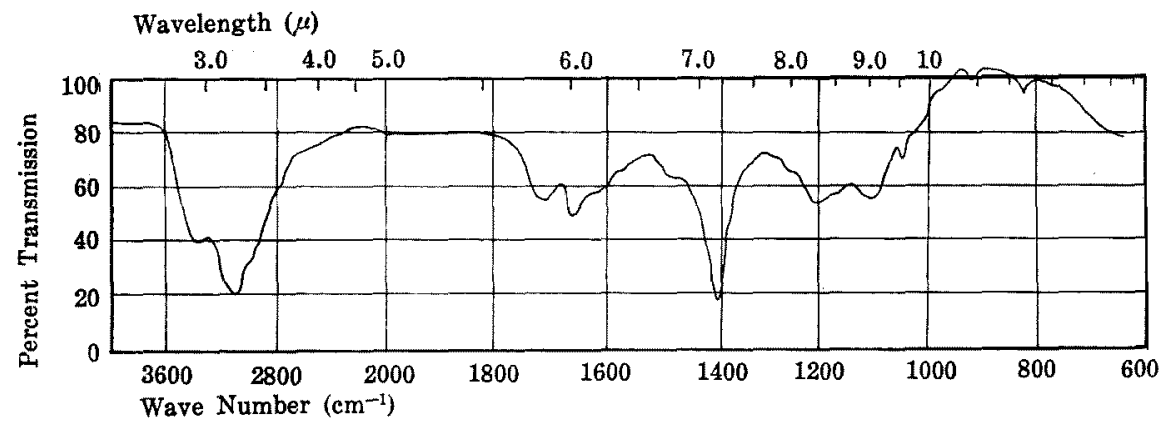

Fig. 6. Infrared spectrum of analipine.

By these treatments threonine and serine could be removed completely and the peptide solution free from any ninhydrin-positive impurities was obtained. The solution was evaporated to dryness in a vacuum desiccator and analipine was crystallized from $85 \%$ ethanol, of which yield was about $50 \mathrm{mg}$. Fig. 5 is a photomicrograph showing the cross-shaped crystals of analipine.

Properties of analipine Analipine had m. p. $197-199^{\circ} \mathrm{C}$. Paper chromatography of analipine was performed by the descending technique on Toyo No. 51 paper. A $0.1 \%$ solution of ninhydrin in $n$ butanol was used for colour development (Table 1). The preparation of analipine gave only one
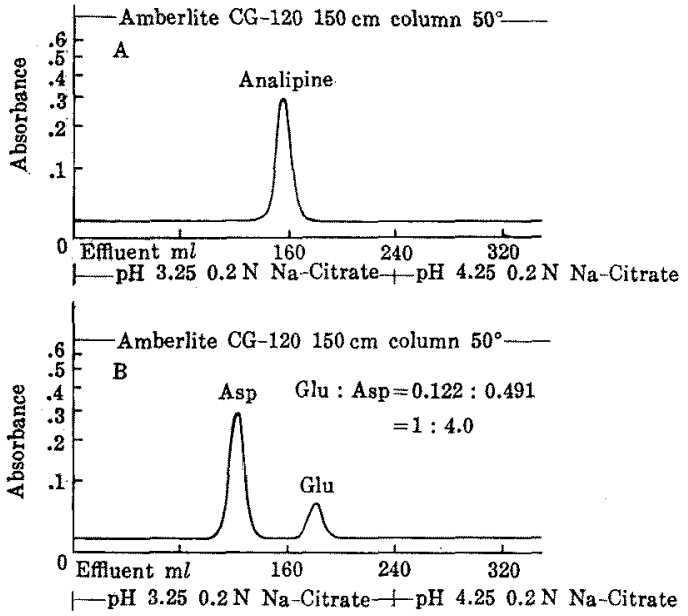

Fig. 7. Amino acid composition of analipine. A, before hydrolysis. B, after hydrolysis. 
spot in various solvent systems used.

Infrared spectrum of analipine is given in Fig. 6. It shows a strong absorption band at $1404 \mathrm{~cm}^{-1}$ and a weak one at $1665 \mathrm{~cm}^{-1}$.

Analipine $(0.2 \mathrm{mg})$ was hydrolysed in a sealed tube with $6 \mathrm{~N} \mathrm{HCl}(2.5 \mathrm{ml})$ at $105^{\circ} \mathrm{C}$ for $24 \mathrm{hr}$, and $\mathrm{HCl}$ was removed by repeated evaporations to dryness in vacuo. The residue was dissolved in water $(10 \mathrm{ml})$ and an aliquot $(4 \mathrm{~m} l)$ was subjected to the Hitachi amino acid analyzer. As shown in Fig. 7, $0.08 \mathrm{mg}$ of analipine gave $0.018 \mathrm{mg}$ of glutamic acid $(0.12 \mu \mathrm{mole})$ and $0.065 \mathrm{mg}$ of aspartic acid $(0.49 \mu \mathrm{mole})$. Consequently, it seems that analipine is a pentapeptide consisting of glutamic acid and aspartic acid or their amide.

\section{Discussion}

Analipine was extracted from the alga with $75 \%$ ethanol instead of hot water which has been used widely for extraction of algal peptides ${ }^{1-5)}$. The use of the aqueous ethanol has advantages that 1) the extraction of the peptide is feasible at room temperature, 2) the concentration of extracts is easy at lower temperature, and 3) the deproteinizing process is excluded. Thus the formation of pyrrolidone ring in N-terminal glutaminyl residue $^{14}$, if present, might be avoidable during the extraction and subsequent concentration processes.

The techniques of gel filtration and column chromatography with bufferized resin were introduced for the first time for isolation of the algal peptide. Although most of impurities could be eliminated easily by these methods, further improvements should be necessary for the preparation of a larger amount of the peptide. At the final stage of the purification, analipine was precipitated with mercuric acetate at $\mathrm{pH} 9$ to remove contaminated threonine and serine. DEKKER et al. ${ }^{6}$ precipitated fastigiatine with mercuric acetate from acidified solution. In our experiments, however, the precipitation of the peptide was incomplete in acidic media.

The biuret reaction of analipine was found to be negative, probably due to the limited amount of the sample used. However, the amino acid analysis of its hydrolysate clearly showed that it is a peptide consisting of glutamic and aspartic acids or their amides. Further chemical properties and the detailed structure of analipine must await the succeeding study.

\section{Acknowledgements}

The authors wish to express their heartiest thanks to Emer. Prof. Dr. Jun TokidA, Hokkaido Univ. and Prof. Dr. Hikoei OHMI, Faculty of Fisheries, Hokkaido Univ. for their encouragements and advices given in the course of preparation of this manuscript. Assistance by Mr. Hiroshi FujIMAKI and Miss Ryoko Aruch in performing a part of the experiments is also acknowledged. 


\section{References}

1) P. HAAs and T. G. HrLl: Biochem. J., 25, 1472-1475 (1931).

2) P. HAAS and T. G. HILL: ibid., 27, 1801-1804 (1933).

3) P. HaAs and T. G. HrL: ibid., 32, 2129-2133 (1938).

4) P. HAAS: ibid., 46, 503-505 (1950).

5) C. A. Dekker, D. Stone, and J. S. Fruton: J. Biol. Chem., 181, 719-729 (1949).

6) D. M. Channing and G. T. Young: J. Chem. Soc., 2481-2491 (1953),

7) D. G. Smith and E. G. Young: J. Biol. Chem., 205, 849-858 (1953).

8) D. G. SMrth and E. G. Young: ibid., 217, 845-853 (1955).

9) E. J. Lewis and E. A. Gonzalves: Ann. of Botany, 26, 301-316 (1962).

10) T. OHIRA: J. Agr. Chem. Soc. Japan, 15, 370-376 (1939).

11) T. OHIRA: ibid., 16, 293-298 (1940).

12) S. Makisumi: J. Biochem., 46, 63-71 (1959).

13) S. Konagaya: This Bull., 32, 967-971 (1966).

14) S. Konagaya: ibid., 33, 417-420 (1967).

15) M. J. WYNNE: Phycologia, 10, 169-175 (1971).

16) K. Narita: in "Tanpakushitsu-Kagaku" (ed. by S. Akabori and S. Mizushima), Vol, 1, Kyoritsu Shuppan, Tokyo, 1954, p. 201. 